\title{
Regional Econometric Housing Start Forecast Accuracy in Florida
}

\author{
Thomas M. Fullerton, Jr. and Carol A. Taylor West*
}

\begin{abstract}
Regional econometric forecasting accuracy assessment has traditionally received less attention than its national macroeconometric counterpart. While evidence is available that state and local employment forecasts perform well relative to standard benchmarks, little is known about the historical performance of widely cited regional housing start forecasts. This paper attempts to fill partially that gap in the literature by assessing the accuracy of previously published residential construction forecasts for Florida and its six largest metropolitan areas. Results indicate that regional econometric housing start forecasts are less reliable than regional employment structural model forecasts.
\end{abstract}

\section{INTRODUCTION}

Systematic accuracy assessment of national macroeconomic forecasts has long been a staple in applied econometric research efforts (Ashley 1988; Fisher and Wallis 1990; McKnees 1992). Less work has been compiled at the regional and metropolitan subnational levels of aggregation. This is in spite of the fact that the precision of construction sector projections has long been identified as a critical determinant of comparative metropolitan statistical area (MSA) forecast accuracy (Taylor 1982). A major component of urban construction market activity is housing starts, but metropolitan residential building forecasts have not been subjected to the historical scrutiny afforded to their collective macroeconomic counterpart (McKnees 1976, 1981; McKnees and Ries 1983; Su 1978). Literature on the empirical accuracy of any U.S. urban area forecasts consists of three articles (Conway 1990; Taylor and Theil 1988; West and Fullerton 1996a) and none considers the important housing sector.

Construction sector forecast accuracy is a critical determinant of aggregate economy forecast precision in many high-growth Sunbelt states. This has long been recognized from model test simulations across different MSA markets (Taylor 1982) and recent business cycle fluctuations have served to highlight its importance. In rapid-growth regions, above average increases in jobs and population, plus the concomitant demand for new work space and residences, expand the roles of construction and its support activities in the employment base. Examples of the support activities include construction materials mining, manu-

\footnotetext{
*The authors are, respectively, Assistant Professor, Department of Economics and Finance and Texas Center for Border Economic Development, University of Texas at El Paso, El Paso, TX; and Chair, Department of Economics, and Director of Forecasting, University of Florida, Gainsville, FL. Partial funding support for this research was provided by the University Research Institute at the University of Texas at El Paso, the Public Policy Research Center at the University of Texas at El Paso, the Center for the Study of Western Hemispheric Trade at the University of Texas at El Paso, and El Paso Electric Company. Material presented in this paper has benefited measurably from the detailed comments provided by three anonymous referees. Econometric research assistance was provided by George Escobedo, Juan Alberto Luevano, Mika Laaksonen, Josemanuel Mascareñas, and Roberto Coronado.
} 
facturing, and wholesaling. Also included are public utilities, household durable goods retailing, real estate, and local government permitting and licensing. Because construction activities are interest rate sensitive, restrictive monetary policy tends to cause fairly sharp reactions in high-growth states. That is due to the relatively large roles played by construction and constructionrelated activities in the economy at large. Those effects are compounded by the reduction in overall demographic mobility during business cycle downturns. National recessions accompanied by badly deteriorating home sales markets tend to exhibit a severe dampening effect on regional migratory patterns, thus exacerbating the initial impacts of building cutbacks in fast-growing regions (Clark 1982; Gordon 1985; Greenwood 1997; Miller 1995; Molho 1984; Oglivy 1979, 1982; Pissarides and Wadsworth 1989; Smith and Fishkind 1985).

The business cycle role of construction, especially residential construction, in subnational economies has increased during the last quarter century. That has raised the vulnerability of fast- growth regions to economic slowdowns. Florida's history is illustrative. Between 1950 and 1995, the state's annual average employment growth of 4.9 percent was more than twice that of the United States mean of 2.1 percent. Examination of this period indicates that the relatively high rate of expansion does not appear to have been accompanied by high growth instability. Specifically, volatility can be calculated as follows:

$$
=\left[\operatorname{Sum}((\text { Actual Growth }- \text { Trend Growth }) / \text { Trend Growth })^{2} / \mathrm{n}\right]^{0.5},
$$

where percentage trend growth is measured as the fitted value of a linear regression of the actual percentage growth rate on a logarithm of time.

Using variation around trend as a percentage of trend in this manner yields a Florida employment volatility estimate of 0.58 . The corresponding national employment volatility measure of 0.90 is much higher. If the sample is shortened to include only the 1972-1995 rapid-change period in Florida (West 1995), the two figures are much closer together. Although Florida's volatility increases to 0.73 , it is still smaller than the corresponding value for the entire country, 0.88 . A question arises as to why Florida is less volatile than the national economy during the pre-1972 portion of the sample.

Special factors contributed to each of the pre-1972 national economic recessions. A sharp decline occurred in federal spending following the end of the Korean War in 1954. Automobile sales dropped rapidly in 1958. A widespread steel strike took place in 1960. In 1970, automobile unions and workers at General Electric went on strike. With very little of its employment base in durable manufacturing, Florida was relatively immune to the pre-1972 recessions that affected so many other regions of the national economy.

In 1974, however, an international energy supply shock led to a downturn characterized by double-digit inflation and severe credit crunches. The latter triggered an unprecedented postwar housing collapse. Nationally, the peak-to-trough decline in residential fixed investment reached nearly 30 percent. 
In the five previous postwar recessions, housing investment grew in three, fell 2.7 percent in one, and declined 10.9 percent in another. During the first oil shock recession, Florida housing starts fell by more than 67 percent, net migration dropped by more than 70 percent, state job losses were proportionally larger than those of the national economy, and the unemployment rate increment exceeded the national average (West and Lenze 1997).

The 1981-82 recession was also accompanied by a national housing market nosedive. Similarly to 1974 , mortgage rates were driven up by tighter monetary policy. The 1990-91 business cycle downturn included several construction phenomena in addition to higher mortgage rates. The 1986 federal tax reforms reversed most of the artificial stimuli provided by the 1981 tax code, leading to a multiyear building curtailment in multifamily residential construction. Excess office and apartment space had previously been put into place in many metropolitan markets, further exacerbating the downturn in economic activity. Finally, development funding was in short supply due to the savings and loan crisis. In both recessions, Florida housing start contractions exceeded the national cutbacks, while the state unemployment peaks neared or surpassed those for the nation as a whole. Peak-to-trough job cuts were less severe in Florida than in the rest of the nation in the 1981-82 recession, but were proportionally deeper in the Sunshine State during the 1990-91 cyclical downswing (see West and Lenze 1997).

Despite the importance of construction in many Sunbelt regional economies, forecast accuracy of regional construction has not been systematically examined. As noted above, the literature to date on analyzing the empirical precision of any state or urban forecasts in the United States is surprisingly small. More attention has focused on national forecast reliability, frequently including residential building (McKnees 1978, 1979, 1992; Su 1978). There is little reason, however, to assume that forecast accuracy results for national construction variables apply to state and local economies. Regional construction forecasts depend critically on migration flows, for instance, while national construction markets may be affected at most by overall mobility with scant attention paid to migratory destinations.

The research at hand uniquely addresses this issue by assessing the accuracy of previously published ex ante state and metropolitan area housing start forecasts from structural econometric models. Structural model housing start forecast data are widely available and generally used as construction market indicators throughout the nation. In addition, they allow comparison with national forecast accuracy findings. Residential construction activity forecast data are assembled for the state of Florida and its six largest urban economies. Recent housing market literature has emphasized the use of multi-equation structural models for national impact analysis (DiPasquale and Wheaton 1992, 1994). Similar models are also used to generate urban area forecasts that serve as inputs to both corporate and government agency planning activities. Benchmarking forecast accuracy is central to a research agenda that responds to the demand for these 
forecasts and complements the use of structural models for simulation impact analysis. Methodological benchmarking in local area housing analysis has been introduced into the field of estimation procedures (Gatzlaff and Ling 1994). The material at hand extends such efforts to forecast procedures.

Specifically analyzed is the predictive accuracy of state and metropolitan housing starts for the 1986-1995 sample period. The period under consideration includes a complete business cycle and is sufficiently long to permit analysis of forecasts of up to ten quarters ahead. Results uncovered below differ from those associated with national housing activity forecasts, underscoring the importance of not assuming that national results will apply systematically to regional and metropolitan markets. The study reinforces what has been observed in empirical estimation of other local housing market models, especially hedonic housing price models. Namely, that there is substantial variation in the effectiveness of a given model or methodology across urban areas (Knight, Hill, and Sirmans 1993). Patterns of metropolitan housing start accuracy also fail to follow the pattern found to exist for area employment projections during the same sample period, emphasizing the unique nature of housing markets within local economies.

It is important to highlight the selection of housing starts as a component of regional economic activity forecasts. From a practical perspective, these data are available in a timely manner from a variety of municipal, state, and federal statistical sources. That is in contrast to other regional economic indicator measures, such as gross state product, that become available only after a long lag or may not be available at all at the substate level of disaggregation. On a related note, housing start data are available from public sources and not subject to proprietary limitations on distribution and publication like some of the residential and nonresidential construction series marketed by private corporate entities. Finally, residential construction activities represent key elements in rapidly growing southern and western Sunbelt regions and play central roles in business cycle fluctuations in Florida and its MSAs (West 1995). Subsequent sections of the paper include a review of the literature, discussion of the methodology, empirical analysis, and suggestions for future research.

\section{NATIONAL HOUSING START FORECAST ACCURACY}

There have been a variety of studies that have looked at national housing start forecast accuracy in at least a cursory manner. Given its importance as a key element in business cycle analysis, the relative lack of detailed formal attention given to residential construction activity is curious. The few studies that have helped to bridge this gap generally do so in conjunction with the traditional macroeconomic forecasting focus on gross domestic product, inflation, and interest rates. To date, there has been no research of this nature conducted for subnational housing markets. A short review of the national literature provides, therefore, a logical starting point for this paper. 
The first of the early studies to examine housing start forecast accuracy came in an extension of a previous article on macroeconometric forecast evaluation (McKnees 1976). Total housing start forecasts published by four separate organizations are examined for accuracy relative to a random walk alternative. The 1971-1976 sample period includes all three phases of at least one complete business cycle-expansion, contraction, and recovery. Theil inequality coefficients are calculated for forecast step lengths of one to six quarters ahead. The central conclusions of this initial paper are that predictive performances of the various models and techniques were fairly similar and that they compare favorably to the no-change baseline alternative. Not surprisingly, mean absolute forecast errors increased as a function of simulation period length.

Subsequent research (Su 1978) reviewed considers total housing start forecasts from two sources over a somewhat longer sample period, 1968-1977. Multiple-step forecast lengths are analyzed, with eight quarters ahead representing the longest period utilized. Prediction accuracy deteriorates as a function of forecast period length. The sample period includes two complete business cycles. Evidence reported by the author indicates that precise turning point prediction is an elusive goal. McNees (1979) also obtained similar results for a sample period covering 1970-1979.

Unlike the situation facing decision makers and market analysts at the regional and metropolitan levels, there are a fairly large number of econometric forecasts available for the national macroeconomy. McNees (1981) examines the comparative accuracy of thirteen different organizations, although not all of the study participants provided housing start projections. Average absolute errors for national housing start forecasts are found to reach 200,000 units or more by the eighth quarter of the 1976-1980 sample period analyzed.

A follow-up study (McKnees and Ries 1983) underscores the volatile nature of housing starts and illustrates the difficulty associated with forecasting this variable. Extension of the earlier sample period to 1983 allowed another business cycle downturn to be included in the analysis. The addition of only a few new observations caused the Theil inequality coefficients for housing starts to partially reverse their earlier pattern. As a result, the U-statistic at quarter 8 was lower than that at quarter 6, while the latter was smaller than the inequality coefficient at quarter 4 . While some leveling off at longer step lengths is not uncommon, the pattern uncovered by McNees and Ries (1983) is surprising. Recent evidence (McKnees 1992) indicates that, in absolute terms, national housing start forecast errors will generally tend to increase as a function of prediction step length.

\section{DATA AND METHODOLOGY}

Although there have been a number of studies conducted with respect to the accuracy of national housing start forecasts, similar research has not been conducted at the regional level. Mills and Lubuele (1995) note that many MSA 
forecasting models are proprietary, a situation that has hampered comparative methodological analysis. The track records are also typically proprietary, hampering forecast accuracy analysis. In addition, MSA forecasting has a far shorter history than its national counterpart. Only recently have a large sample of forecasts become available for any region. A full business cycle of observations is essential given that forecast accuracy is well known to vary as a function of point-in-time aggregate trends (Theil 1967; Mills and Lubuele 1995; Taylor and Theil 1988).

Historical forecasting records from the long-established University of Florida research program provide the data base for the current study. Ex ante quarterly forecasts for total housing starts in Florida and its six largest metropolitan economies are examined. Data are assembled from quarterly forecasts published between 1985 and 1995, with a maximum forecast period length of ten quarters (West and Fullerton 1996b). While larger samples, both geographic and temporal, are always desirable, this set of 2,195 point forecasts provides a reasonable base to initiate research on urban housing market forecast accuracy.

The six metropolitan economies included in the sample provide an interesting cross section of regional markets to analyze. Ft. Lauderdale has observed increases in both international trade and business services in recent years. Jacksonville has shifted away from its traditional reliance on pulp/paper and food process manufacturing to finance, insurance, and health care services, along with the development of cargo port facilities. Miami remains a hub for import/export activity (Fullerton 1995), warehousing and distribution, and medical equipment manufacturing.

In addition to its mammoth tourism and convention sector, Orlando is also an important defense and aerospace manufacturing center. Tampa-St. PetersburgClearwater has long served as a well-known destination for both retirees and "snowbirds," but has also emerged as an important data processing and telemarketing hub in recent years. International trade and telecommunications manufacturing are also becoming important in the Bay Area. Perhaps most surprising is the rural/urban mix of West Palm Beach-Boca Raton, where agriculture, semiconductors, and telecommunications coexist within a single county (West 1995).

The diversity of the six MSA residential construction markets and their underlying economic bases helps guarantee that the statistical analysis herein will not be unduly influenced by overall trends affecting individual sectors of the state economy. Economic conditions facing the Florida economy, as well as its various sectors and metropolitan regions, varied substantially over the period under consideration. Briefly, the sample period includes the fast-growth years of the mid-1980s, the recession of the early 1990s, and the cyclical recovery of the mid-1990s. Concomitant effects were also observed in housing activity, ensuring that the accuracy levels, or lack thereof, attributed to the ex ante forecasts published for Florida and its six major urban centers are not overstated as a result of special conditions relating to specific trends that are easily modeled. 
While some regional economies in the United States observed only shallow and brief recessions in the early 1990s, this was not the case in Florida. Total employment fell in both 1991 and 1992 for the state as a whole, and fell in 1991 in all six metropolitan economies in the sample. Real per capita incomes also fell in 1991 in the state and in five of the six MSAs and remained below their 1990 levels until at least 1993. The one exception to that pattern was Greater West Palm Beach, where a relatively high number of retirees allowed strength in dividend, interest, and rental incomes plus transfer payments to barely offset weaknesses in labor earnings (West and Lenze 1997). As the accompanying figures illustrate, the impact of the recession on residential construction activity was particularly severe. National housing starts fell by approximately 190,000 units in 1991 . Florida, with only 5.2 percent of the national population, accounted for 21.6 percent, or nearly 41,000 units, of that total.

Florida and its six largest MSAs also represent a good test cae for benchmarking regional housing start forecast accuracy from another perspective. Rapidly changing demographic patterns have characterized all of the regional economies under consideration in the paper. This factor radically increases the standard difficulties associated with residential construction forecasts (Berson 1997; DiPasquale and Wheaton 1994). Given this, the sample utilized herein provides a useful starting point for attempting to assess the historical validity of this class within regional and urban econometric forecasting analysis.

To evaluate the relative accuracy of these regional residential construction forecasts, univariate ARIMA models are estimated and simulated for the state and metropolitan total housing start series across each of the 38 sample subperiods. The resulting simulation results are then segregated by quarters-ahead forecast. Accordingly, 37 one-step forecasts are obtained, 36 two-step forecasts, and so forth. The structural model forecasts previously published by the University of Florida are segregated in an identical manner. These models are set up in a standard satellite arrangement utilizing the Standard \& Poor's DRI national macroeconometric model as the source for many of the exogenous variable forecasts (Bolton 1985). The urban models are of the smaller system of equation variety discussed in Taylor (1982).

In the case of Orlando, the forecast test period only reaches through the first quarter in 1993. Prior to that year, this central Florida metropolitan area was composed of only three counties, Orange, Osceola, and Seminole. Changing commuting patterns and demographic expansion led the Census Bureau to add Lake County to the Orlando metropolitan area definition in 1992. As a result of the definition break point, the analysis conducted for Orlando is accomplished with only 29 one-step forecasts, 28 two-step forecasts, and continuing in this manner to 20 ten-step forecasts.

Forecast data segregated by step length are compared with actual housing start estimates for each quarter in the sample period. The resulting prediction errors are then used to calculate root mean squared error (RMSE) values for all 
ten forecast period groupings. Modified Theil inequality coefficients are then calculated as the ratios of the structural model RMSEs to those associated with the univariate ARIMA housing start equations. Modified inequality coefficients, also known as U-coefficients, estimated in this manner are generally regarded as good benchmarks for gauging the predictive accuracy of econometric forecasting models (Kolb and Stekler 1990; Webb 1984; West 1996). Both measures are calculated using the traditional formulations for each individual extrapolation step length:

$$
\text { RMSE }_{\mathrm{i}}=\left[\operatorname{Sum}(\text { Econometric Error })^{2} / \mathrm{n}\right]^{0.5} /\left[\operatorname{Sum}(\text { ARIMA Error })^{2} / \mathrm{n}\right]^{0.5} \text {, }
$$

where $n$ equals the number of forecast observations for step length $i$. Forecast step lengths range from one quarter ahead to ten quarters ahead in terms of out-sample-simulation periods.

A modified inequality coefficient of less than one indicates that the structural model forecasts for that step length are more accurate than those of the ARIMA counterpart. Conversely, a U-coefficient of greater than one implies that the univariate time series model generates smaller absolute forecast errors for the step length in question. In cases where the RMSEs for both methods are equal, a value of one results, implying that neither technique outperforms the other.

While the modified U-coefficients provide an attractive starting point, it is possible that univariate ARIMA equations do not provide more stringent benchmarks than do random walk forecasts. To allow for this possibility, a separate set of Theil inequality coefficients are calculated using the formula from above wherein the denominator now includes the RMSE calculated for a lagged observation forecast rule. Similar to the ARIMA RMSE case, a U-coefficient of less than one indicates that the structural model housing start forecasts outperformed the random walk counterparts. An inequality coefficient of greater than one implies the converse. Because less comprehensive testing was conducted in the earlier studies of national residential construction activity, the work at hand provides a more rigorous examination of the structural forecasting approach.

Conducting a more thorough examination of regional forecasts is probably mandatory because these data are typically more volatile than their national counterparts. For the 1967-1995 sample period selected for this paper, the ratio of the standard deviation to the mean for national housing starts is 23.5 percent. The corresponding figure for Florida housing starts is much higher, at 34.3 percent. Given the larger variances that will generally be associated with state and metropolitan economic time series, it makes sense to consider more than one benchmark when examining questions regarding predictive accuracy. To address this concern at least partially, an additional set of accuracy comparisons is developed using random walk benchmarks for the state and MSA forecasts.

\section{EMPIRICAL RESULTS}

Functional form for univariate ARIMA models depends critically upon the stationarity characteristics associated with the series being modeled. As shown by 
the unit root tests reported in Table 1, all seven housing start data series required first-order differencing to obtain stationarity. This is irrespective of the level of statistical significance selected for the MacKinnon critical values for hypothesis rejection. While not shown in the tabulated results, the pattern also holds no matter what sample period is selected for analysis. Table 1 lists the full-sample period tests and thus includes the contractionary business cycle phases of the early 1990s in Florida. On the basis of the information provided by Table 1, all of the housing series are differenced prior to modeling.

TABLE 1

Augmented Dickey-Fuller Unit Root Tests for Stationarity

\begin{tabular}{ccccccc}
\hline Region & Level ADF Statistic & Critical Values & First Difference ADF & Critical Values \\
\hline Florida & -2.631 & -4.076 & $1 \%$ & -4.941 & -4.077 & $1 \%$ \\
& & -3.466 & $5 \%$ & & -3.467 & $5 \%$ \\
& & -3.159 & $10 \%$ & & -3.160 & $10 \%$
\end{tabular}

\begin{tabular}{lll} 
Ft. Lauderdale & -2.703 & -5.011 \\
Jacksonville & -2.034 & -4.128 \\
Miami & -2.758 & -5.020 \\
Orlando & -1.354 & -5.077 \\
Tampa & -2.021 & -4.081 \\
West Palm Beach & -2.498 & -4.964 \\
\hline
\end{tabular}

As is the case with national data, state and metropolitan housing starts are more volatile than most other regional economic variables. In spite of that fact, and the wide variety of market conditions present in the sample period selected for analysis (West 1995; West and Lenze 1997), the univariate ARIMA equation specifications listed in Table 2 do not change very often. For the state as a whole, only one model specification change is necessary. For Jacksonville, Orlando, and West Palm Beach-Boca Raton, two alterations to the initial respective equation formats are introduced. In the cases of Ft. Lauderdale, Miami, and TampaSt. Petersburg-Clearwater, the same univariate ARIMA model frameworks are maintained for all 38 sample subperiods.

TABLE 2

Final Univariate ARIMA Housing Start Model Specifications

\begin{tabular}{llc}
\hline Region & Final Equation Specification & Number of Specification Changes \\
\hline Florida & MA(11) & 1 \\
Ft. Lauderdale & MA(1) & 0 \\
Jacksonville & AR(3), MA(1) & 2 \\
Miami & MA(2) & 0 \\
Orlando & MA(4,10) & 2 \\
Tampa & AR(11), MA(1) & 0 \\
West Palm Beach & AR(1),MA(7) & 2 \\
\hline
\end{tabular}

Modified Theil inequality coefficient results using the standard Box-Jenkins equations are reported in Table 3 . Using $U<1.0$ as a general guideline, it is apparent that the structural model forecasts compare favorably to the univariate ARIMA benchmarks. In 48 of the 70 inequality coefficients estimated, results of 0.99 or less are observed. Similarly to West and Fullerton (1996a), no distinct 
temporal patterns emerge with respect to the relative accuracy of the two extrapolation methodologies. It is particularly worth noting that the outcome for one step ahead is not necessarily a predictor of outcomes at higher step lengths or averages across multiple step lengths. The absence of distinct temporal patterns in Table 3 confirms findings of recent research in local area forecast combination (West 1996), as well as empirical analysis of sources of variation in MSA construction markets (Coulson 1993). In Jacksonville, Orlando, and West Palm Beach, the structural model forecasts enjoyed lower RMSEs at all ten step lengths. In Miami and Tampa, the ARIMA benchmark simulations generally provided more accurate housing start forecasts. These ARIMA results are in contrast to evidence reported for nonagricultural employment forecasts assembled for these MSAs (West and Fullerton 1996a). For Florida in its entirety, the results are evenly split between the structural econometric and univariate time series techniques.

TABLE 3

Econometric vs. ARIMA Theil Inequality RMSE Ratios

\begin{tabular}{lccccccccccc}
\hline MSA & U1 & U2 & U3 & U4 & U5 & U6 & U7 & U8 & U9 & U10 & Average \\
\hline Florida & 0.74 & 0.83 & 0.99 & 1.01 & 1.11 & 1.13 & 1.09 & 1.01 & 0.94 & 0.92 & 0.97 \\
Ft. Lauderdale & 1.02 & 0.92 & 0.96 & 0.95 & 0.86 & 0.84 & 0.78 & 0.76 & 0.74 & 0.69 & 0.85 \\
Jacksonville & 0.85 & 0.77 & 0.92 & 0.82 & 0.77 & 0.69 & 0.65 & 0.60 & 0.59 & 0.58 & 0.72 \\
Miami & 1.05 & 1.23 & 1.27 & 1.24 & 1.30 & 1.25 & 1.12 & 0.92 & 0.90 & 0.92 & 1.12 \\
Orlando & 0.61 & 0.55 & 0.68 & 0.71 & 0.71 & 0.69 & 0.64 & 0.59 & 0.53 & 0.50 & 0.62 \\
Tampa & 0.86 & 1.30 & 1.32 & 1.34 & 1.46 & 1.51 & 1.44 & 1.43 & 1.35 & 1.32 & 1.33 \\
West Palm Beach & 0.69 & 0.67 & 0.76 & 0.84 & 0.90 & 0.95 & 0.94 & 0.94 & 0.94 & 0.92 & 0.86 \\
Average & 0.83 & 0.90 & 0.99 & 0.99 & 1.06 & 1.01 & 0.95 & 0.90 & 0.86 & 0.84 & 0.93 \\
\hline
\end{tabular}

While providing valuable comparison information, the inequality coefficients have a drawback associated with them. Namely, that there is no means by which to tell when a difference in the relative accuracies of two competing prediction methodologies is statistically significant. Statistical testing and inference is problematic due to the fact that forecast errors generally are serially correlated. This condition is further complicated by the contemporaneous correlation of forecast residuals generated by alternative techniques. These difficulties, coupled with the predominance of small sample sizes, have traditionally forced practitioners to rely on descriptive measures of relative forecast precision (Howrey, Klein, and McCarthy 1974; Mizrach 1992). To circumvent this problem, a handful of potential tests have been proposed (Kolb and Stekler 1990; Diebold and Mariano 1995), including both parametric and nonparametric procedures. Separate research has shown that in spite of its interpretive difficulties, the descriptive information provided by Theil inequality measures performs reliably (West 1996). Given that, additional statistical testing with respect to the ARIMA prediction errors and forecast rankings presented in Table 3 is not undertaken.

The possibility exists, of course, that it may possible to obtain superior housing start forecasts by utilizing a random walk procedure (Ashley 1988; West and Fullerton 1996a). Under this approach, the last available historical observation is used as the forecast for all target periods. Results associated 
with the random walk assumption are reported in Table 4. Unlike the ARIMA benchmarks, the random walk assumption fares unexpectedly well against the previously published structural forecasts. In only half of the 70 comparison cases reported in Table 4 is $U<1.0$. Furthermore, on average, the random walk forecasts are slightly more accurate than the structural model simulation output. Because residential construction activity is strongly cyclical, it is surprising that a simple prediction rule that overlooks that aspect of the sector is so successful (for a discussion of construction cycles, see DiPasquale and Wheaton 1996).

TABLE 4

Econometric vs. Random Walk Theil Inequality RMSE Ratios

\begin{tabular}{lccccccccccc}
\hline MSA & U1 & U2 & U3 & U4 & U5 & U6 & U7 & U8 & U9 & U10 & Average \\
\hline Florida & 0.76 & 0.91 & 1.06 & 1.10 & 1.21 & 1.22 & 1.18 & 1.11 & 1.04 & 1.03 & 1.06 \\
Ft. Lauderdale & 0.90 & 0.97 & 1.00 & 0.93 & 0.85 & 0.82 & 0.78 & 0.73 & 0.67 & 0.62 & 0.83 \\
Jacksonville & 0.87 & 0.86 & 1.07 & 1.01 & 1.01 & 0.93 & 0.89 & 0.86 & 0.84 & 0.83 & 0.92 \\
Miami & 1.25 & 1.55 & 1.64 & 1.46 & 1.57 & 1.37 & 1.14 & 0.91 & 0.84 & 0.84 & 1.26 \\
Orlando & 0.76 & 0.69 & 0.87 & 0.83 & 0.82 & 0.83 & 0.85 & 0.76 & 0.71 & 0.73 & 0.79 \\
Tampa & 0.97 & 1.39 & 1.40 & 1.43 & 1.55 & 1.58 & 1.54 & 1.50 & 1.44 & 1.40 & 1.42 \\
West Palm Beach & 0.84 & 0.81 & 0.94 & 1.03 & 1.09 & 1.16 & 1.15 & 1.14 & 1.14 & 1.09 & 1.04 \\
Average & 0.91 & 1.03 & 1.14 & 1.11 & 1.16 & 1.13 & 1.08 & 1.00 & 0.95 & 0.93 & 1.04 \\
\hline
\end{tabular}

The relatively strong showing of the random walk forecasts also varies from earlier results regarding the accuracy of regional econometric forecasts for Florida and its MSAs (West and Fullerton 1996a). Structural model forecasts of nonagricultural employment clearly outperform the naïve forecasts over the 1985:4-1992:2 period. The study at hand adds nearly three years of additional quarterly forecast observations to the earlier employment analysis, but eliminating these observations from the current sample does not change the overall results in either study.

Four other factors may contribute to the reversal in results between the two studies. Two relate to quality and availability. First, greater measurement error undoubtedly characterizes the housing start data, decreasing the ability to describe it accurately with a structural model. Employment data used in West and Fullerton (1996a) are nonsurvey ES-202 data from unemployment insurance reports. Total housing start series are derived from start-to-permit ratios based on survey data, a process that definitely introduces measurement error into estimation. Second, even in the absence of housing start measurement error, reliable regional data on vacancy rates are not available. Because vacancy is such an important determinant of new residential construction volumes (Topel and Rosen 1988; DiPasquale and Wheaton 1994), the absence of such information for state and metropolitan markets poses a serious obstacle to accurately predicting regional housing starts. As noted in the appendix material below, an overbuilding indicator variable is constructed as a vacancy proxy, but this measure provides only a crude measure of how regional vacancy rates may change over time. While incomplete data for regional employment modeling is also an econometric fact of life, reasonable substitutes for missing items are more readily available. 
The other two factors derive from the quality of the forecasts entering housing start equations relative to those incorporated into the employment specifications. First, national forecast variables used as regressors in state and local construction market equations may be less accurately projected than the right-hand-side variables in regional employment equations. Of note here is the difficulty in forecasting interest rates, a particularly problematic issue given the interest sensitivity of residential construction (Cooper and Nelson 1972; McKnees 1992). Second, local construction sector dependency on forecast local population growth may introduce considerable reverberative error in out-ofsample model simulations (Charney and Taylor 1984). In rapidly growing states like Florida, net migration is the principal component underlying population expansion. Net migration flows are dependent on the difficult-to-forecast composite variable of local labor market conditions relative to the national job market.

The composite labor market input variable to the net migration equations may be constructed as the difference between local and national unemployment rates (themselves subject to measurement error) and / or employment growth rates. Small relative errors in the individual area rates readily escalate into large relative errors in the difference of the two rates. Furthermore, national housing market conditions affect overall population mobility, so errors in macroeconomic residential real estate forecasts easily compound into large regional extrapolation errors. For example, when interest rate forecasts are low, they directly tend to cause housing start overestimates derived from resident demand. The low interest rates additionally bolster outlooks for national housing markets, increasing net migration and stimulating even greater regional housing starts in response to new population inflows. The overestimation of housing starts overstates construction jobs, improving regional labor market conditions relative to the nation, a shift that triggers more in-migration and construction activity. In short, the potential for reverberative forecast error compounding is particularly large with respect to the model interactions between net migration and regional housing starts.

Note that many of these same four factors also help explain more successful housing market forecasts from structural models at the national level compared to the state and local levels. Survey inputs into national construction data series are more reliable than those for regional data. A greater number of series are available for macroeconometric model building, permitting more complete model specification that is less reliant on proxy estimates. Additionally, accurate modeling of interregional migration does not play the critical role in national housing industry analysis that it does in state and MSA forecasting efforts.

Whether random walk residential construction predictive superiority is unique to Florida is an open question. Regional econometric forecast evaluation is a segment of the literature that remains relatively uncharted. While previous evidence indicates that total metropolitan employment is forecast more accurately using structural models (West and Fullerton 1996a), overall construction employment (residential and nonresidential) is generally more difficult to model. 
Comparative studies for other regions in the United States and other countries would help shed additional light on this possibility.

From a practitioner perspective, it is important to note that so-called random walk or lagged historical observation forecasts are regarded as complementary inputs to structural model simulation forecasts. Many professional econometricians refer to random walk predictions as "sanity checks." Given this, plus the results in Table 4, a logical step to contemplate is the incorporation of some sanity into the frequently insane world of regional housing start forecasting analysis. Granger and Ramanathan's (1984) composite forecasting procedure provides a potential candidate methodology. Fullerton (1989) provides regional evidence of the composite procedure applicability using state-level sales tax collections.

To examine whether the two sets of forecasts contain complementary information, individual regression equations are estimated for each of the forecast step lengths. The dependent variable in each equation is the number of actual housing starts and the corresponding regressors are the steps-ahead econometric forecasts and random walk lags. In all, 70 equations are estimated, corresponding to the seven regions analyzed and the one through ten quarters ahead forecast periods under consideration. This exercise is completed twice-first, for the entire sample extrapolation period and second, for just the first half of the test forecast period, 1986-1990. The latter regressions are utilized in spite of relatively few degrees of freedom because ordinary least squares minimizes the sum of squared errors, thus the composite weights estimated over the entire forecast period are likely by construction to generate lower inequality coefficients than the random walk comparison forecasts.

Table 5 lists the combination weights for Florida and each of the six major metropolitan areas for the complete sample period. Similarly to Fullerton (1989), the structural forecast regression weights do not follow any discernible patterns. There are two instances for the Ft. Lauderdale data in which the lagged observation forecasts receive negative combination weights. Negative regression parameter estimates also occur for nine of the ten simulation step lengths estimated for the simultaneous equation forecasts for Tampa. As discussed in Cooper and Nelson (1972), negative combination weights result when forecast residual correlation coefficients exceed the ratio of the standard deviations of each methodology's respective residuals.

Let $\mathrm{r}$ represent the correlation coefficient for the structural model and random walk residuals, with $\mathrm{s}_{\mathrm{ectrc}}$ and $\mathrm{s}_{\mathrm{rw}}$ as the standard deviations for the two forecasting approaches. The regression coefficient for the econometric forecasts will be negative whenever $r>s_{r w} / s_{\text {ectrc }}$ while the regression parameter for the lagged observation forecasts will be negative in cases where $r>s_{\text {ectrc }} / s_{\mathrm{rw}}$. These relations result from the fact that minimizing the sum of squared residuals when forecast errors are correlated causes heavier weight to be attached to the prediction with the smallest variance. This is a process analogous to selecting a portfolio containing two securities and selling short the more risky of the two (Cooper and Nelson 1972). 
TABLE 5

Full Sample 1986-1995 Housing Start Forecast Combination Weights

\begin{tabular}{lcccccccccc}
\hline MSA & Q1 & Q2 & Q3 & Q4 & Q5 & Q6 & Q7 & Q8 & Q9 & Q10 \\
\hline Florida & & & & & & & & & & \\
Structural Model & 0.77 & 0.60 & 0.44 & 0.41 & 0.32 & 0.30 & 0.31 & 0.35 & 0.43 & 0.44 \\
Random Walk & 0.23 & 0.40 & 0.56 & 0.59 & 0.68 & 0.70 & 0.69 & 0.65 & 0.57 & 0.56 \\
Ft. Lauderdale & & & & & & & & & & \\
Structural Model & 0.60 & 0.54 & 0.50 & 0.60 & 0.73 & 0.82 & 0.91 & 0.98 & 1.08 & 1.20 \\
Random Walk & 0.40 & 0.46 & 0.50 & 0.40 & 0.27 & 0.18 & 0.09 & 0.02 & -0.08 & -0.20 \\
Jacksonville & & & & & & & & & & \\
Structural Model & 0.70 & 0.70 & 0.44 & 0.50 & 0.49 & 0.56 & 0.63 & 0.69 & 0.76 & 0.80 \\
Random Walk & 0.30 & 0.30 & 0.56 & 0.50 & 0.51 & 0.44 & 0.37 & 0.31 & 0.24 & 0.20 \\
Miami & & & & & & & & & & \\
Structural Model & 0.28 & 0.21 & 0.20 & 0.25 & 0.20 & 0.28 & 0.39 & 0.63 & 0.82 & 0.81 \\
Random Walk & 0.72 & 0.79 & 0.80 & 0.75 & 0.80 & 0.72 & 0.61 & 0.37 & 0.18 & 0.19 \\
Orlando & & & & & & & & & & \\
Structural Model & 0.62 & 0.29 & 0.61 & 0.67 & 0.75 & 0.71 & 0.70 & 0.86 & 1.00 & 0.94 \\
Random Walk & 0.38 & 0.71 & 0.39 & 0.33 & 0.25 & 0.29 & 0.30 & 0.14 & 0.00 & 0.06 \\
Tampa & & & & & & & & & & \\
Structural Model & 0.56 & -0.05 & -0.06 & -0.02 & -0.10 & -0.14 & -0.15 & -0.20 & -0.22 & -0.26 \\
Random Walk & 0.44 & 1.05 & 1.06 & 1.02 & 1.10 & 1.14 & 1.15 & 1.20 & 1.22 & 1.26 \\
West Palm Beach & & & & & & & & & & \\
Structural Model & 0.83 & 0.91 & 0.61 & 0.45 & 0.38 & 0.30 & 0.32 & 0.32 & 0.31 & 0.35 \\
Random Walk & 0.17 & 0.19 & 0.39 & 0.55 & 0.62 & 0.70 & 0.68 & 0.68 & 0.69 & 0.65 \\
\hline
\end{tabular}

In general, the results indicate that both sets of residential construction forecasts are useful and tend to complement each other. To examine this inference more closely, composite forecasts are assembled using the combination weights listed in Table 5. RMSEs are then calculated for the composite forecasts. In order to assess projection accuracy, the latter are then compared to the random walk RMSEs. Modified Theil inequality coefficients from this exercise are reported in Table 6. Without exception, the composite housing start forecasts are at least slightly more accurate than the random walk last observation approach. This holds true for all ten forecast period lengths and all seven forecast regions. On average, the smallest improvement is observed in Tampa. All other regions exhibit RMSEs that are at least 9 percentage points lower than the random walks. The evidence reported in Table 6 strongly suggests that for series that are difficult to forecast, formal sanity checks such as the composite structural-random walk simulations examined herein may prove useful. Both approaches seemingly provide useful information that tends to be complementary rather than overlapping.

As a cautionary check on the results listed in Tables 5 and 6, a separate set of tests is completed wherein only the first half of the forecast sample (1986-1990) is used to estimate the combination weights. Modified Theil inequality coefficients are then calculated by applying those weights to the housing start forecasts for the 1991-1995 portion of the forecast period. These steps are taken due to the fact that least squares estimation of the combination weights will, by construction, tend to generate lower RMSEs than those calculated for either component series as a consequence of minimizing the sum of squared residuals. 
TABLE 6

Full Sample 1986-1995 Composite Theil Inequality RMSE Ratios

\begin{tabular}{lccccccccccc}
\hline MSA & U1 & U2 & U3 & U4 & U5 & U6 & U7 & U8 & U9 & U10 & Average \\
\hline Florida & 0.73 & 0.84 & 0.89 & 0.90 & 0.93 & 0.94 & 0.95 & 0.95 & 0.94 & 0.94 & 0.90 \\
Ft. Lauderdale & 0.82 & 0.88 & 0.91 & 0.87 & 0.82 & 0.81 & 0.77 & 0.73 & 0.67 & 0.60 & 0.79 \\
Jacksonville & 0.84 & 0.82 & 0.89 & 0.85 & 0.82 & 0.82 & 0.82 & 0.82 & 0.82 & 0.82 & 0.83 \\
Miami & 0.95 & 0.94 & 0.95 & 0.93 & 0.95 & 0.92 & 0.89 & 0.86 & 0.83 & 0.83 & 0.91 \\
Orlando & 0.56 & 0.81 & 0.76 & 0.76 & 0.79 & 0.80 & 0.81 & 0.76 & 0.71 & 0.73 & 0.75 \\
Tampa & 0.91 & 0.99 & 0.99 & 0.99 & 0.99 & 0.99 & 0.99 & 0.98 & 0.98 & 0.98 & 0.98 \\
West Palm Beach & 0.83 & 0.81 & 0.84 & 0.93 & 0.94 & 0.96 & 0.95 & 0.96 & 0.96 & 0.96 & 0.91 \\
Average & 0.81 & 0.87 & 0.89 & 0.89 & 0.89 & 0.89 & 0.88 & 0.87 & 0.84 & 0.84 & 0.87 \\
\hline
\end{tabular}

Table 7 contains the split-sample composite forecast weights. Coefficients associated with the structural forecasts are larger than those estimated for the random walk counterparts in 49 of the 70 linear regressions. Negative combination weights result for a handful of the random walk forecasts associated with Ft. Lauderdale, Orlando, and West Palm Beach. Similarly to the full-sample results, nine of the ten econometric forecasts for Tampa carry negative algebraic signs. Given the full-sample results discussed above, it should come as no surprise that the composite coefficients estimated using the split sample also follow no discernible pattern with respect to the length of the forecast period under consideration.

TABLE 7

Split Sample 1986-1990 Housing Start Forecast Combination Weights

\begin{tabular}{|c|c|c|c|c|c|c|c|c|c|c|}
\hline$\overline{\mathrm{MSA}}$ & Q1 & Q2 & Q3 & Q4 & Q5 & Q6 & Q7 & Q8 & Q9 & $\bar{Q} 10$ \\
\hline $\begin{array}{l}\text { Florida } \\
\text { Structural Model } \\
\text { Random Walk }\end{array}$ & $\begin{array}{l}0.77 \\
0.23\end{array}$ & $\begin{array}{l}0.79 \\
0.21\end{array}$ & $\begin{array}{l}0.68 \\
0.32\end{array}$ & $\begin{array}{l}0.58 \\
0.42\end{array}$ & $\begin{array}{l}0.34 \\
0.66\end{array}$ & $\begin{array}{l}0.25 \\
0.75\end{array}$ & $\begin{array}{l}0.22 \\
0.78\end{array}$ & $\begin{array}{l}0.37 \\
0.63\end{array}$ & $\begin{array}{l}0.59 \\
0.41\end{array}$ & $\begin{array}{l}0.51 \\
0.49\end{array}$ \\
\hline $\begin{array}{l}\text { Ft. Lauderdale } \\
\text { Structural Model } \\
\text { Random Walk }\end{array}$ & $\begin{array}{l}0.38 \\
0.62\end{array}$ & $\begin{array}{l}0.57 \\
0.43\end{array}$ & $\begin{array}{l}0.60 \\
0.40\end{array}$ & $\begin{array}{l}0.53 \\
0.47\end{array}$ & $\begin{array}{l}0.59 \\
0.41\end{array}$ & $\begin{array}{l}0.64 \\
0.36\end{array}$ & $\begin{array}{l}0.73 \\
0.27\end{array}$ & $\begin{array}{l}0.87 \\
0.13\end{array}$ & $\begin{array}{r}1.01 \\
-0.01\end{array}$ & $\begin{array}{r}1.23 \\
-0.23\end{array}$ \\
\hline $\begin{array}{l}\text { Jacksonville } \\
\text { Structural Model } \\
\text { Random Walk }\end{array}$ & $\begin{array}{l}0.66 \\
0.34\end{array}$ & $\begin{array}{l}0.78 \\
0.22\end{array}$ & $\begin{array}{l}0.49 \\
0.51\end{array}$ & $\begin{array}{l}0.56 \\
0.44\end{array}$ & $\begin{array}{l}0.57 \\
0.43\end{array}$ & $\begin{array}{l}0.70 \\
0.30\end{array}$ & $\begin{array}{l}0.76 \\
0.24\end{array}$ & $\begin{array}{l}0.87 \\
0.13\end{array}$ & $\begin{array}{l}0.91 \\
0.09\end{array}$ & $\begin{array}{l}0.95 \\
0.05\end{array}$ \\
\hline $\begin{array}{l}\text { Miami } \\
\text { Structural Model } \\
\text { Random Walk }\end{array}$ & $\begin{array}{l}0.35 \\
0.65\end{array}$ & $\begin{array}{l}0.42 \\
0.58\end{array}$ & $\begin{array}{l}0.47 \\
0.53\end{array}$ & $\begin{array}{l}0.62 \\
0.38\end{array}$ & $\begin{array}{l}0.60 \\
0.40\end{array}$ & $\begin{array}{l}0.73 \\
0.27\end{array}$ & $\begin{array}{l}0.85 \\
0.15\end{array}$ & $\begin{array}{l}0.86 \\
0.14\end{array}$ & $\begin{array}{l}0.93 \\
0.07\end{array}$ & $\begin{array}{l}0.95 \\
0.05\end{array}$ \\
\hline $\begin{array}{l}\text { Orlando } \\
\text { Structural Model } \\
\text { Random Walk }\end{array}$ & $\begin{array}{l}0.57 \\
0.43\end{array}$ & $\begin{array}{l}0.32 \\
0.68\end{array}$ & $\begin{array}{l}0.64 \\
0.36\end{array}$ & $\begin{array}{l}0.74 \\
0.26\end{array}$ & $\begin{array}{l}0.91 \\
0.09\end{array}$ & $\begin{array}{l}0.83 \\
0.17\end{array}$ & $\begin{array}{l}0.79 \\
0.21\end{array}$ & $\begin{array}{l}0.95 \\
0.05\end{array}$ & $\begin{array}{r}1.04 \\
-0.04\end{array}$ & $\begin{array}{l}0.94 \\
0.06\end{array}$ \\
\hline $\begin{array}{l}\text { Tampa } \\
\text { Structural Model } \\
\text { Random Walk }\end{array}$ & $\begin{array}{l}0.42 \\
0.58\end{array}$ & $\begin{array}{r}-0.18 \\
1.18\end{array}$ & $\begin{array}{r}-0.34 \\
1.34\end{array}$ & $\begin{array}{r}-0.32 \\
1.32\end{array}$ & $\begin{array}{r}-0.49 \\
1.49\end{array}$ & $\begin{array}{r}-0.52 \\
1.52\end{array}$ & $\begin{array}{r}-0.50 \\
1.50\end{array}$ & $\begin{array}{r}-0.60 \\
1.60\end{array}$ & $\begin{array}{r}-0.63 \\
1.63\end{array}$ & $\begin{array}{r}-0.68 \\
1.68\end{array}$ \\
\hline $\begin{array}{l}\text { West Palm Beach } \\
\text { Structural Model } \\
\text { Random Walk }\end{array}$ & $\begin{array}{l}0.86 \\
0.14\end{array}$ & $\begin{array}{r}1.12 \\
-0.12\end{array}$ & $\begin{array}{l}0.95 \\
0.05\end{array}$ & $\begin{array}{l}0.68 \\
0.32\end{array}$ & $\begin{array}{l}0.56 \\
0.44\end{array}$ & $\begin{array}{l}0.45 \\
0.55\end{array}$ & $\begin{array}{l}0.54 \\
0.46\end{array}$ & $\begin{array}{l}0.57 \\
0.43\end{array}$ & $\begin{array}{l}0.55 \\
0.45\end{array}$ & $\begin{array}{l}0.56 \\
0.44\end{array}$ \\
\hline
\end{tabular}

Modified Theil U-statistics for the split-sample forecast combination weights are reported in Table 8. In contrast to the full-sample results shown in Table 6, there is virtually no improvement in average forecast accuracy that results 
from combining the econometric forecasts with the random walks. In only two of the metropolitan areas, Ft. Lauderdale and Orlando, is there any appreciable reduction in the RMSEs relative to the random walk benchmarks. For the sample as a whole, the RMSE ratio equals 0.99 , indicating that there is little to be gained from this approach to residential construction activity prediction. Regional and metropolitan housing start forecast accuracy would thus appear to be a highly elusive target within the category of subnational econometric modeling research.

TABLE 8

Split Sample 1991-1995 Composite Theil Inequality RMSE Ratios

\begin{tabular}{lccccccccccc}
\hline MSA & U1 & U2 & U3 & U4 & U5 & U6 & U7 & U8 & U9 & U10 & Average \\
\hline Florida & 0.69 & 0.97 & 1.01 & 0.98 & 0.99 & 0.99 & 0.99 & 0.99 & 1.01 & 0.97 & 0.96 \\
Ft. Lauderdale & 0.77 & 0.92 & 0.94 & 0.85 & 0.82 & 0.84 & 0.81 & 0.78 & 0.72 & 0.68 & 0.81 \\
Jacksonville & 0.76 & 0.89 & 0.89 & 0.98 & 1.10 & 1.19 & 1.20 & 1.23 & 1.08 & 1.10 & 1.04 \\
Miami & 0.95 & 1.09 & 1.24 & 1.28 & 1.31 & 1.30 & 1.12 & 0.81 & 0.88 & 0.71 & 1.07 \\
Orlando & 0.60 & 0.85 & 0.79 & 0.81 & 0.94 & 0.96 & 0.91 & 0.85 & 0.76 & 0.73 & 0.82 \\
Tampa & 0.70 & 1.09 & 1.12 & 1.23 & 1.24 & 1.31 & 1.25 & 1.25 & 1.21 & 1.14 & 1.15 \\
West Palm Beach & 0.83 & 1.12 & 1.21 & 1.17 & 1.13 & 1.22 & 1.20 & 1.08 & 1.03 & 1.02 & 1.10 \\
Average & 0.76 & 1.01 & 1.03 & 1.04 & 1.08 & 1.12 & 1.07 & 0.99 & 0.96 & 0.91 & 0.99 \\
\hline
\end{tabular}

\section{CONCLUSION}

Despite the large amount of attention given to them by the media and by commercial subscribers, regional housing start forecasts have previously not been tested for forecast accuracy. This research partially fills that gap in the literature by evaluating the historical track record for quarterly housing start forecasts in Florida and its six largest metropolitan economies. The sample includes a wide variety of regional economies and the time period covers expansion, contraction, and recovery phases of the national business cycle.

Evidence reported above indicates that regional structural model forecasting performance associated with total housing starts is acceptable with respect to that associated with a univariate ARIMA benchmark. The same cannot be said with regard to a random walk prediction rule, a surprising outcome in light of the cyclical nature of residential construction activity. These results suggest that additional research is necessary, especially given the widespread usage of regional housing forecasts. A potentially worthwhile first step in this direction is provided by an examination of whether information contained in the structural forecasts is complemented by that provided by random walk projections. Results indicate, however, that a composite projection approach is not likely to improve the accuracy of the regional housing activity forecasts.

Given the absence of other studies in this branch of the literature, additional verification of these results would be helpful. Future research may also segment residential construction forecasts into component parts where possible. It would be useful to examine, for instance, whether the empirical results reported above can be replicated for both single-family housing starts as well as multiunit dwelling structures. The latter segment of the residential building market tends to be relatively volatile and may be harder to model and forecast than the former. 
Because the data set is drawn from only one state, examination of housing start forecast accuracy for other regions would help identify whether the results discussed above are unique to Florida. Due to the importance of this category of regional economic forecasting analysis, more attention is certainly merited. This point is further highlighted by the fact that the empirical analysis discussed above does not parallel the evidence uncovered for national housing start forecast accuracy or that reported for state and metropolitan nonagricultural employment predictions.

\section{APPENDIX}

\section{Specification of the Florida Short-Term State and Metropolitan Area Econometric Modeling System}

\section{A. Overview and Evolution}

The first edition of The Florida Outlook, the quarterly publication of the Florida short-term state and metropolitan area econometric modeling system, appeared in 1977:1. Metropolitan area forecasts were gradually added over the next six years. In 1984, procedures for seasonally adjusting data were updated, major changes were introduced to the state model structure, and all remaining metropolitan statistical areas MSAs were added to the system. Quarterly frequency forecasts were consistently produced using the modeling system from mid-1985 through mid-1996 and it is this period that is covered in the current research.

The state model requires forecasts from a national macroeconomic model. The twenty MSA models run as satellites to both the state and national models. Numerous small and moderate changes were made to the modeling system throughout the 1980s and 1990s. Examples include changes in standard industrial classification (SIC) aggregations to reflect the 1987 SIC manual update; the addition of specialized banking and airline employment categories to permit isolation and tracking of unusual closure and merger impacts; specification changes to account for major revisions to regional income series, national income and product accounts, and national industrial production indices; changes in regional specifications to reduce dependency on national variables characterized by relatively low forecast accuracy; and experimentation with competing specifications. Examples of the latter include attempts to improve construction employment prediction accuracy by adding greater detail in the construction activity module; investigation of whether earnings per employee by industrial category could be forecast more accurately by adding "leading sector" components such as regional manufacturing wages; estimation of MSA labor earnings per job and nonlabor earnings per capita in a cross section time series system instead of within individual MSA models.

Three major changes were made to the modeling system in 1993. First, the nonmetropolitan (rest-of-the-state) model was substantially modified to reflect the fact that its employment base was no longer primarily comprised by jobs in rural counties. By 1993, nonmetropolitan jobs were increasingly dominated by 
SIC 73, temporary and leased employment, spread across numerous MSAs rather than being assigned to a specific location. Second, changes in MSA definitions resulting from the 1990 decennial census were incorporated into historical data and equation specifications. Third, the "state" model was changed from a single area model into an add-up of two geographic regions: a combination of the Ft. Lauderdale and Miami MSAs and Florida net of these two southeastern urban economies. Hurricane Andrew caused large income, employment, sales, and population shifts following its landfall in August 1992. The bulk of these shifts were concentrated in Broward and Dade counties, which jointly account for approximately one-fourth of Florida's population and economic activity. Separating the two counties facilitated better tracking of the storm impacts as data became available. From a simulation perspective, this separation also appropriately buffered the forecasts for most of Florida from the effects of exogenously imposed uncertain hurricane reconstruction activity and population dispersion.

Given this ongoing model maintenance as a function of the evolving regional economies in Florida, changing institutions, inevitable data revisions, variable definition changes, demographic boundary shifts, uneven macroeconomic forecast accuracy, and improved forecasting techniques, it is impossible to write "the model" that generated the forecasts used in this study. A general framework can be outlined, however, that delineates the detail typically incorporated into the modeling system, along with its major equation blocks, over the course of the decade under consideration.

\section{B. The State Model}

Dividing the state model into two geographical pieces in 1993 did not substantially affect model detail or theoretical specification. Rather, it generally created two equations where before there had been only one. The two exceptions are tourist arrivals (for which only statewide data are available) and detailed income components (for which only statewide data are available at a quarterly frequency). To limit the length of the state model description, revisions to specifications and data series that distinguish Miami/Ft. Lauderdale from the rest of Florida are not delineated. Major model blocks include nonagricultural employment, personal income, demography and the labor market, construction activity, and tourism. Individual components in each block are identified below along with their major explanatory variables.

\section{Employment}

Phosphate fertilizers are one of Florida's major international exports. Phosphate mining employment is modeled as a function of phosphorus mining output, a weighted dollar exchange rate, and a real wage rate. Most of Florida's other mining is quarry activity that generates gravel, clay, and other inputs for both residential and nonresidential construction. Other mining employment is dependent on housing starts, construction employment, and a real wage measure. 
Construction employment is modeled as a function of new construction activity, population, and consumer confidence.

Although distance from markets traditionally meant that Florida did not have significant industrial segments in its economic base, manufacturing has become fairly important during the postwar period (West 1995). Durable manufacturing employment is separated into three component series in the state model. The first is made up of construction-related durable manufacturing employment in structural lumber, furniture, and stone, clay, and glass (SICs 24, 25 , and 32). It is modeled as a function of construction activity, construction employment, a real wage variable, and national labor productivity trends in SICs 24, 25, and 32. High-tech and defense-related durable manufacturing employment (SICs 36, 37, and 38) is dependent on inflation-adjusted federal defense expenditures, industrial production indices for defense and aerospace manufacturing, national labor productivity trends, and dummy variables for anticipated program cancellations. Durable manufacturing employment not elsewhere classified is run as a function of construction employment and durable and nondurable manufacturing employment subcomponents.

Nondurable manufacturing employment is also divided into three major categories. The first is printing and publishing, which is modeled and forecast as a function of total state employment and national labor productivity in SIC 27. Food processing employment, long important in this agricultural region, is dependent on population, Florida citrus production, and national labor productivity in SIC 20. Other nondurable manufacturing employment runs as a function of U.S. employment in apparel manufacturing and paper and products (SICs 23 and 26), Florida phosphate production, and a weighted dollar exchange rate.

Also divided into three separate series and stochastic equations is employment in transportation, communications, and public utilities. Airline employment is modeled as a function of tourist arrivals by air, Florida population, Florida nonagricultural employment, a real wage variable, and exogenous structural impacts such as the PanAmerican Airways and Eastern Airlines closures of the early 1990s. Water transportation jobs are modeled as a function of inflationadjusted U.S. exports and imports, Florida phosphate production, a real wage index, and automobile imports. Regulated industry employment not elsewhere classified is dependent on Florida population, construction employment, and a real wage variable.

The traditional breakdown of trade employment into the retail and wholesale divisions is utilized in the modeling system. The relatively low wage and very widespread, retail trade segment has a large range of right-hand side variables. They include tourist visits, state population, personal income, consumer confidence, unemployment, construction employment, housing starts, real minimum wage, and the national trend in the ratio of part-time to full-time employment. Explanatory variables for wholesale trade employment include Florida retail trade employment, Florida goods-producing employment (mining, manufacturing, and construction), and other state employment. 
Jobs in finance, insurance, and real estate are segmented into two components, banking and nonbanking. Banking sector employment regressor variables include construction employment, construction activity, Florida population, and a trend variable representing bank merger impacts on total jobs (case in point is the recent merger between Barnett Banks and NationsBank). Employment other than banking is a function of interest rates, recent variation in interest rates, construction employment, construction activity, and income net of transfer payments.

Service sector employment is divided into four categories. Hotel and motel jobs are modeled as dependent upon total tourist visits, lagged contracting for new hotel construction, and the minimum wage adjusted for inflation. Business services employment right-hand side variables include total nonagricultural employment and a trend variable representing the utilization of temporary help employment agencies. Medical services employment explanatory variables include population by age group weighted by relative age group usage of health care services, real income, and real wages. Services employment not elsewhere classified is a function of Florida population, national consumer confidence, national per capita real expenditures on "other" services, state per capita income relative to national per capita income, and wages adjusted for inflation.

Public sector jobs are broken into two basic categories. State and local government employment is dependent upon total state population, the proportion of Florida population that is school aged, real personal income, and the state unemployment rate. Federal government employment is modeled as a function of population, a trend variable for national federal government employment, military employment, and a dummy variable to account for additional workers associated with decennial census year head count efforts.

\section{Personal Income}

Labor and proprietary earnings are modeled individually for six separate industrial categories. Manufacturing compensation is a function of total manufacturing employment and its sectoral distribution, plus national compensation per employee trends in manufacturing, and the Florida unemployment rate relative to that of the United States. Earnings in transportation, communications, and public utilities are dependent on employment in these sectors, wage levels in Florida manufacturing, a relative unemployment measure, and national compensation trends in regulated industries. Compensation in finance, insurance, and real estate is modeled as a function of financial sector employment, interest rates, the Standard \& Poor's 500 stock index, and a national salary index for the sector as a whole. Wages, salaries, and proprietary earnings in trade activities are specified as dependent upon total employment in wholesale and retail trade and their respective shares, the U.S. minimum wage, and a relative unemployment rate variable. Independent variables for service sector incomes include total services employment, the national minimum wage, and Florida unemployment relative to national unemployment. Regressor variables for government wages and salaries include 
total public sector jobs, a U.S. public agency compensation trend series, and the relative unemployment rate index.

Dividend, interest, and rent income is dependent on Florida population; national dividend, interest, and rent income per capita; the share of U.S. dividend, interest, and rent income that is interest; the ratio of the Florida population share over the age of 65 to the national population share over the age of 65; and the relative unemployment rate series. Transfer payment income is a function of state population, federal government per capita transfer payments, relative Florida to U.S. population shares 65 years of age or older, and the ratio of real per capita personal income in Florida to that of the nation as a whole. Explanatory variables for personal contributions for social insurance include labor earnings, payroll tax rates and tax contribution ceilings, national payroll taxes as a share of national earnings, Florida earnings per worker relative to those of the U.S. as a whole. Right-hand side variables for residence adjustments to personal income estimates in Florida include labor earnings, the proportion of state jobs in business services, and the proportion of state employment in construction.

\section{Labor and Demography}

Civilian labor force changes are modeled on the basis of movements in the state unemployment rate and demographic trends, namely the sum of Florida population age cohorts multiplied by their respective labor force participation rates. Projected trends in age cohort labor participation rates are derived from the University of Florida long-term state economic forecasting project (West and Lenze 1997). Explanatory variables for the state unemployment rate include the national jobless rate and the nonagricultural employment growth rate in Florida relative to that of the United States. Total household employment is determined by an identity utilizing the state labor force and unemployment rate as inputs.

Net migration is dependent upon national population totals in the relatively mobile age groups of 20 to 35 years and 55 to 70 years. Additional regressors in the net migration equation include several national factors that affect general population mobility, including consumer confidence, unemployment, mortgage rates, home sales, and housing starts. Also included as explanatory variables for net migration are ratios of Florida job growth to that of the U.S. and state joblessness to that of the national economy. Natural increase in population is extrapolated on the basis of a trend pattern derived from the state long-term econometric forecast (West and Lenze 1997). Population is determined by an identity equation using its own lagged value, natural increase, and net migration.

\section{Construction Activity}

Single-family housing starts are dependent on net migration, population growth, mortgage rates, consumer confidence, unemployment, employment growth, the distribution of population in Florida by age cohort, an index of 5-year building trends relative to state household growth, and national housing starts. 
Multifamily housing activity is a function of net migration, population growth, interest rates, consumer confidence, unemployment, jobs growth, the distribution of state population by age cohort, an index of 5-year building trends relative to household expansion, national multifamily housing activity, and dummy variables for federal tax law changes. Residential building awards are also included in the short-term state model. Independent variables for this equation include single-family housing starts, multifamily housing starts, and average value per award by structure type.

Average value per residential construction award for stand-alone and multiunit dwellings are both modeled as functions of activity in their respective categories, national housing trends, Florida per capita income, and national construction deflators. Nonresidential building awards are dependent on state employment growth, residential building starts and awards, and U.S. nonresidential building activity. Nonresidential nonbuilding construction award independent variables include residential and nonresidential building contract awards, federal grants for infrastructure projects, and U.S. nonresidential building activity.

Quarterly frequency metropolitan income data are not estimated by the Bureau of Economic Analysis, making personal income from this source unavailable for Miami and Ft. Lauderdale. University of Florida data updating programs do provide estimates for two broad income measures at the substate level, labor and nonlabor income. Labor income is adjusted by place of residence and contributions for social insurance. It is regressed against quarterly state income data, substate population, and county wage earnings. Nonlabor income is calculated as the sum of dividends, interest, and rent plus transfer payments. Explanatory variables for the latter income component include quarterly state income data and substate population estimates.

To simplify the presentation above, no distinction is made between variables whose influence is built directly into the left-hand side variable and those whose impact is estimated as part of a regression specification. For example, "population" helps determine the simulation value of a dependent variable if that variable is utilized in per capita terms. Population also helps determine the simulation value of a dependent variable when it appears as a regressor in a stochastic equation. The difference is that the per capita specification imposes a unit population elasticity on the relationship, while the latter approach allows for the possibility of a non-unit elasticity.

As earlier noted, Florida phosphate production enters into the phosphate mining employment equation. State phosphate production itself is estimated from a regression that specifies mine output as a function of U.S. fertilizer production, a weighted exchange rate for the dollar, and dummy variables representing expected depletion dates for Florida mines and openings for major international properties. All other mining activity in Florida is essentially related to the production of construction materials. Chemical manufacturing employment, SIC 28 , has a large phosphate fertilizer component. Florida citrus production 
forecasts are obtained from the University of Florida Institute for Food and Agricultural Sciences and enter as exogenous inputs to the model.

A set of exogenous structural impact dummy variables were utilized in the early and mid-1990s to reflect the expected rebound of airline employment in Miami following the closure of Eastern Airlines in January 1991. This event eliminated a large component of state airline employment, but left behind both unused hub capacity and lucrative routes to Latin America. It was correctly anticipated that other companies such as American Airlines would quickly occupy the vacant space and expand into the canceled routes.

Port of Tampa activity is dominated by phosphate production. This occurs through the importation of chemicals to process Florida phosphate as well as through the exportation of phosphate for transport up the Mississippi River to the midwestern farm belt states. Multicollinearity in this equation, plus others that utilize multiple employment series as regressors, has frequently required weighting the independent variables using exogenous information. Weights are derived from input-output tables for this purpose.

Two of the earnings series are not modeled econometrically. Real earnings per employee in Florida construction traditionally changes little over time. That series is projected using an identity defined on its historical average. Florida earnings in mining has frequently undergone very large revisions over time. Real earnings per employee in that sector is consequently treated as a random walk and held constant at the value of its most recent historical observation.

\section{Figure 1: National, State, and Substate Housing Start Figures}

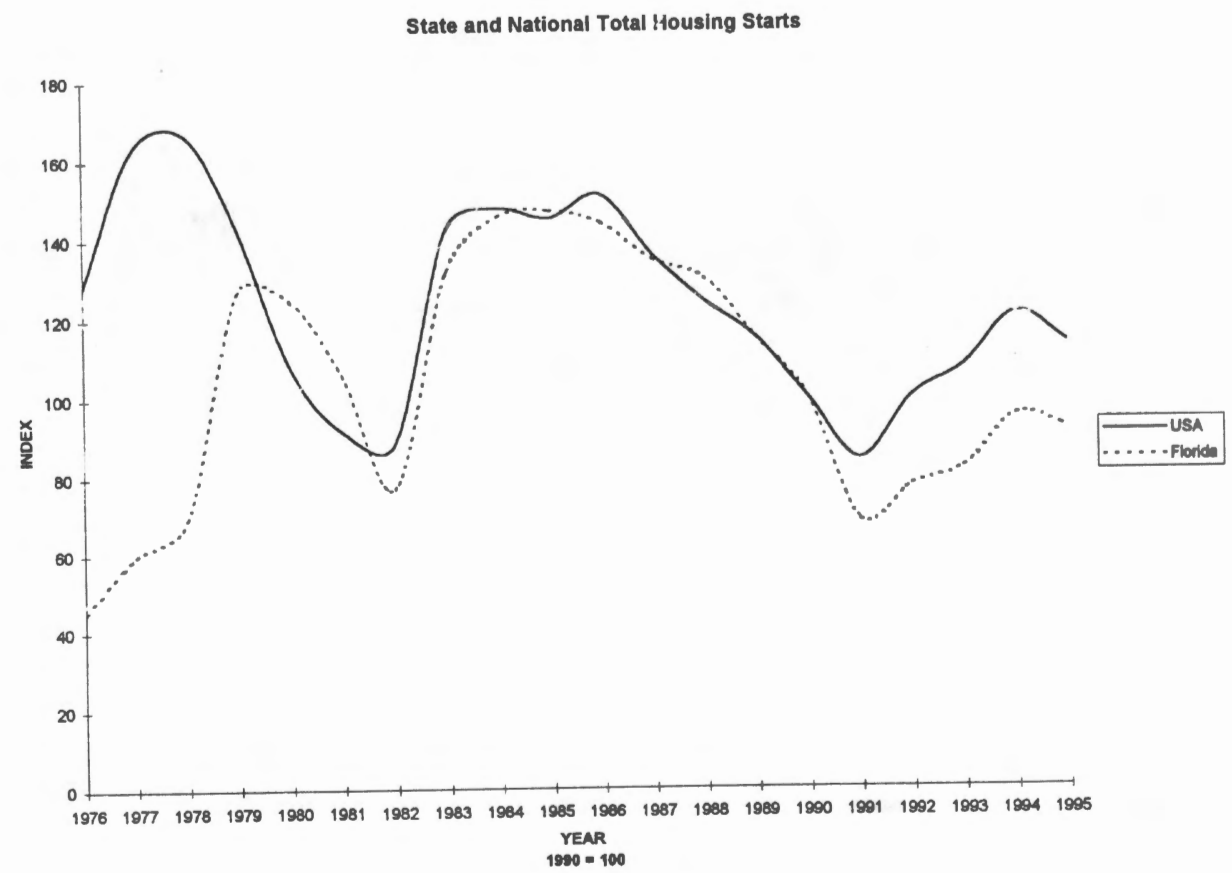




\section{Central and North Florida Total Housing Starts}

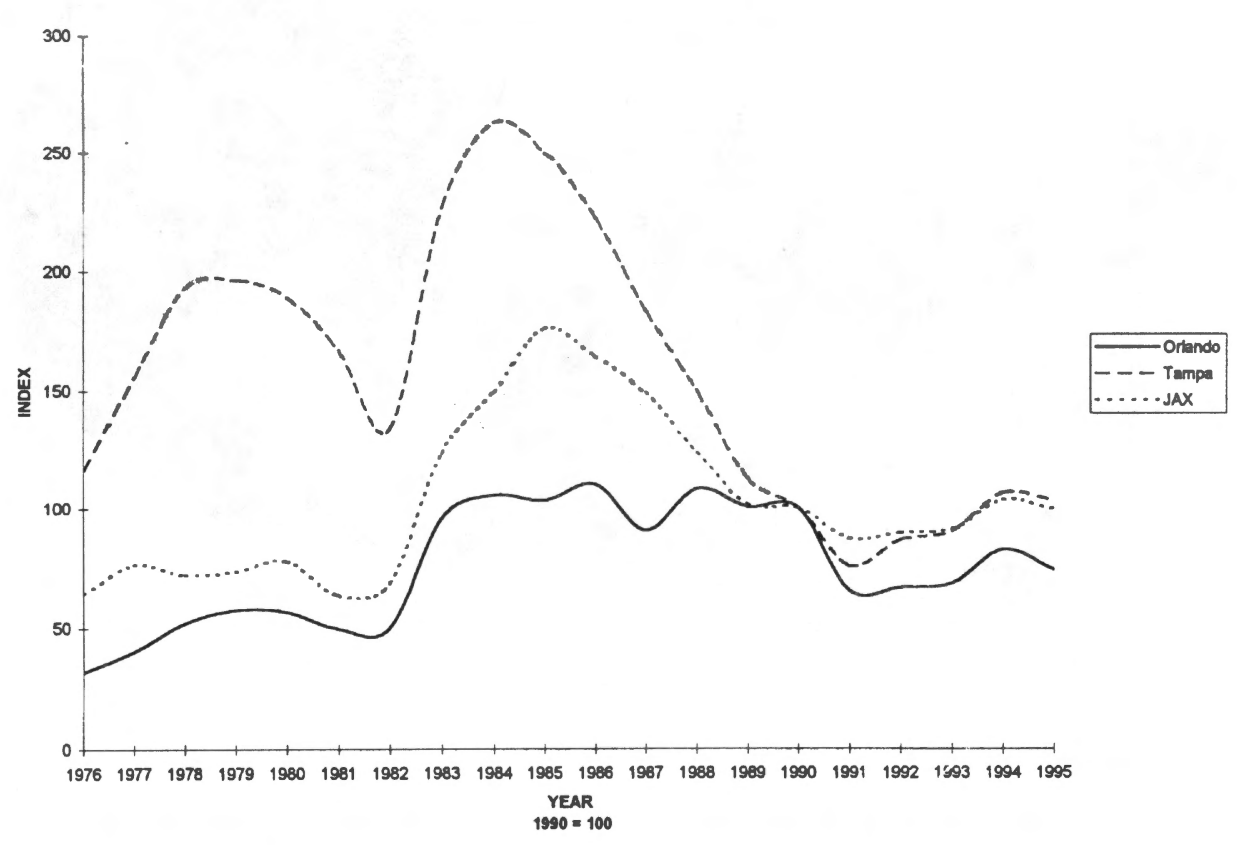

Southeast Florida Total Housing Starts

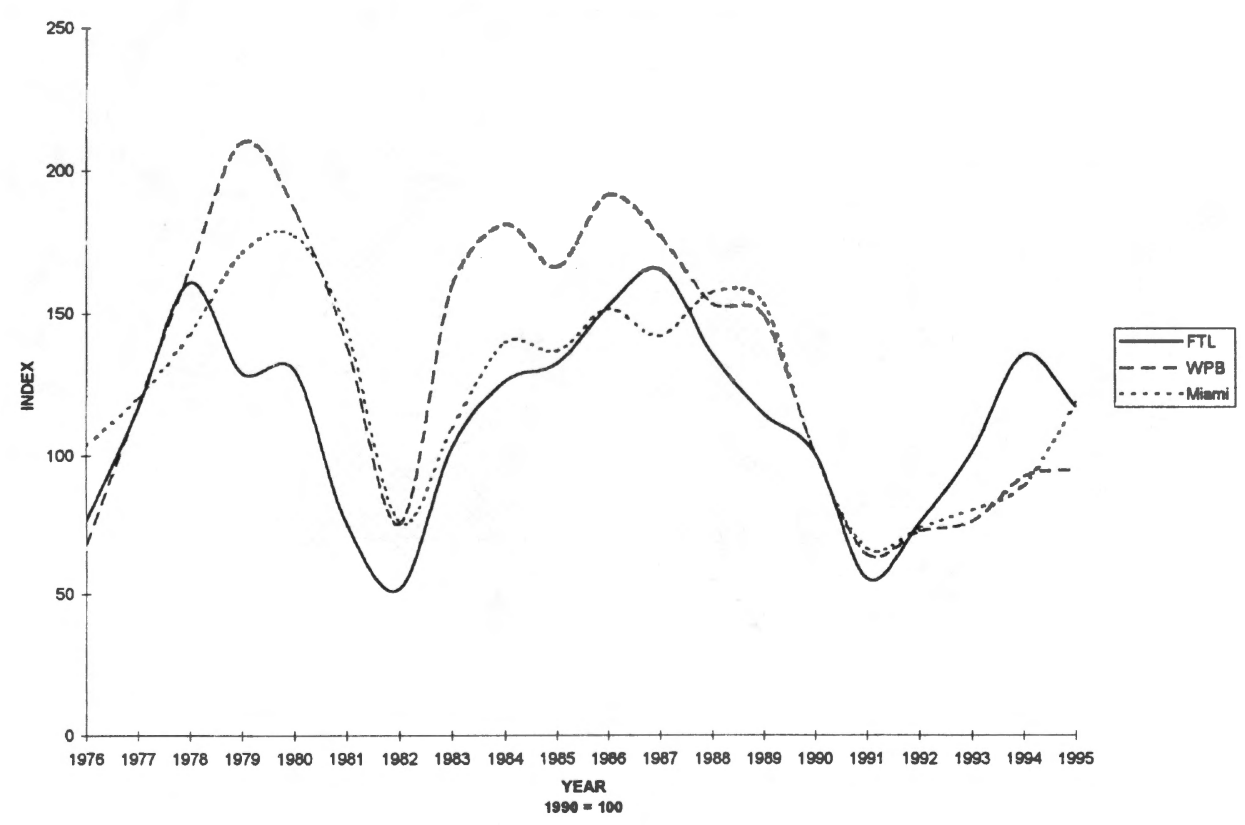


Finally, net migration is impacted by special factors that are also taken into account in the state model design. Migrants to Florida are predominantly young, working age adults or new retirees, causing these age groups within the national population to play critical roles in determining the potential supply of domestic in-migrants to the state. Florida's large "snowbird" population renders national housing pertinent for Florida residential construction activity. In the case of multifamily housing units, the national counterpart also incorporates federal tax law impacts. Given this, the individual regressor variables in this equation are not always statistically significant due to multicollinearity.

\section{REFERENCES}

Ashley, R. "On the Relative Worth of Recent Economic Forecasts." International Journal of Forecasting 4 (1988), 363-376.

Berson, D.W. "The Importance of Demographics in Economic Analysis." Business Economics 32 (January 1997), 12-16.

Bolton, R.E. "Regional Econometric Models." Journal of Regional Science 25 (1985), 495-520.

Charney, A.H., and C.A. Taylor. "Decomposition of Ex-ante State Model Forecasting Errors." Journal of Regional Science 24 (1984), 229-247.

Cooper, J.P., and C.R. Nelson. "The Ex-ante Prediction Performance of the St. Louis and FRB-MIT-Penn Econometric Models and Some Results on Composite Predictors." Journal of Money, Credit, and Banking 4 (1972), 1-32. Clark, G.L. "Volatility and the Geographical Structure of Short-run U.S. Interstate Migration." Environment and Planning A 14 (1982), 145-167.

Conway, R.S., Jr. "The Washington Projection and Simulation Model: a Regional Interindustry Econometric Model." International Regional Science Review 13 (1990), 141-165.

Coulson, N.E. "The Sources of Sectoral Fluctuations in Metropolitan Areas." Journal of Urban Economics 33 (1993), 76-94.

Diebold, F.X., and R.S. Mariano. "Comparing Predictive Accuracy." Journal of Business and Economic Statistics 13 (1995), 253-263.

DiPasquale, D., and W.C. Wheaton. "The Cost of Capital, Tax Reform, and the Future of the Rental Housing Market." Journal of Urban Economics31 (1992), 337-359.

. "Housing Market Dynamics and the Future of Housing Prices." Journal of Urban Economics 35 (1994), 1-27.

. Urban Economics and Real Estate Markets. Englewood Cliffs, NJ: Prentice Hall, 1996.

Fisher, P.G., and K.F. Wallis. "The Historical Tracking Performance of UK Macroeconometric Models 1978-85." Economic Modelling 7 (1990), 179-197. Fullerton, T.M., Jr. "A Composite Approach to Forecasting State Government Revenues." International Journal of Forecasting 5 (1989), 373-380. 
. "International Trade and Investment." In J.F. Scoggins and A.C. Pierce (eds.) The Economy of Florida. Gainesville, FL: University of Florida Bureau of Economic and Business Research, 1995.

Gatzlaff, D.H., and D.C. Ling. "Measuring Changes in Local House Prices: An Empirical Investigation of Alternative Methodologies." Journal of Urban Economics 35 (1994), 221-244.

Gordon, I. "The Cyclical Interaction between Regional Migration, Employment, and Unemployment: A Time Series Analysis for Scotland." Scottish Journal of Political Economy 32 (1985), 135-159.

Granger, C.W.J., and R. Ramanathan. "Improved Methods of Combining Forecasts." Journal of Forecasting 3 (1984), 197-204.

Greenwood, M.J. "Internal Migration in Developed Countries." In M.R. Rosenzweig and O. Stark (eds.) Handbook of Population and Family Economics, Volume 1B. Amsterdam: Elsevier, 1997.

Howrey, E.P., L.R. Klein, and M.D. McCarthy. "Notes on Testing the Predictive Performance of Econometric Models." International Economic Review 15 (1974), 366-383.

Knight, J.R., R.C. Hill, and C.F. Sirmans. "Estimation of Hedonic Housing Price Models using Nonsample Information: A Monte Carlo Study." Journal of Urban Economics 34 (1993), 319-346.

Kolb, R.A., and H.O. Stekler. "The Lead and Accuracy of Macroeconomic Forecasts." Journal of Macroeconomics 12 (1990), 111-123.

McNees, S.K. "An Evaluation of Economic Forecasts: Extension and Update." New England Economic Review (September/October 1976), 30-44.

. "The Rationality of Economic Forecasts." American Economic Review 68

(Papers and Proceedings 1978), 301-305.

"The Forecasting Record for the 1970s." New England Economic Review (September/October 1979), 33-53.

"The Recent Record of Thirteen Forecasters." New England Economic Review (September/October 1981), 5-21.

. "How Large are Economic Forecast Errors?" New England Economic Review (July/August 1992), 25-42.

McNees, S.K., and J. Ries. "The Track Record of Macroeconomic Forecasts." New England Economic Review (November/December 1983), 5-18.

Miller, G.H., Jr. "Dynamics of the U.S. Interstate Migration System, 1975-1992." Growth and Change 26 (1995), 139-160.

Mills, E.S., and L.S. Lubuele. "Projecting Growth of Metropolitan Areas." Journal of Urban Economics 37 (1995), 344-360.

Mizrach, B. "The Distribution of the Theil U-Statistic in Bivariate Normal Populations." Economics Letters 38 (1992), 163-167.

Molho, I. "A Dynamic Model of Interregional Migration Flows in Great Britain." Journal of Regional Science 42 (1984), 317-337. 
Oglivy, A.A. "Migration - the Influence of Economic Change." Futures 11 (1979), 383-394.

. "Population Migration between the Regions of Great Britain, 19711979." Regional Studies 16 (1982), 65-73.

Pissarides, C.A., and J. Wadsworth. "Unemployment and the Inter-Region Mobility of Labor." Economic Journal 99 (1989), 739-755.

Smith, S.K., and H. Fishkind. "Elderly Migration into Rapidly Growing Areas: A Time Series Approach." Review of Regional Studies 15 (1985), 11-20.

$\mathrm{Su}, \mathrm{V}$. "An Error Analysis of Econometric and Noneconometric Forecasts." American Economic Review 68 (Papers and Proceedings 1978), 306-312.

Taylor, C.A. "Econometric Modeling of Urban and Other Substate Areas." Regional Science and Urban Economics 12 (1982), 425-448.

Taylor, C.A., and H. Theil. "Modeling the Accuracy of Certain Regional Predictions." Regional Science and Urban Economics 18 (1988), 453-462.

Theil, H. Economics and Information Theory. Amsterdam: North Holland, 1967.

Topel, R., and S.H. Rosen. "Housing Investment in the United States." Journal of Political Economy 96 (1988), 718-740.

Webb, R.H. "Vector Autogressions as a Tool for Forecast Evaluation." Federal Reserve Bank of Richmond Economic Review 70 (January/February 1984), 3-11.

West, C.T. "Regional Heterogeneity of the Florida Economy." In J.F. Scoggins and A.C. Pierce (eds.) The Economy of Florida. Gainesville, FL: University of Florida Bureau of Economic and Business Research, 1995.

. "System-based Weights vs. Series-specific Weights in the Combination of Forecasts." Journal of Forecasting 15 (1996), 369-383.

West, C.T., and T. M. Fullerton, Jr. "Assessing the Historical Accuracy of Regional Economic Forecasts." Journal of Forecasting 15 (1996a), 19-36.

. "Forecast Summary: Florida Economy," The Florida Outlook 20 (1996b), 11-26.

West, C.T., and D.G. Lenze. "Volume 1: State \& MSAs." The Florida Long-Term Forecast. Gainesville, FL: University of Florida Bureau of Economic and Business Research, 1997. 
